\title{
Ontogeny of Type 1 Angiotensin II Receptor Gene Expression in the Rat
}

\author{
Alda Tufro-McReddie, * Jeffrey K. Harrison, ${ }^{\star}$ Allen D. Everett, * and R. Ariel Gomez * \\ Departments of *Pediatrics and ${ }^{\ddagger}$ Pharmacology, University of Virginia School of Medicine, Charlottesville, Virginia 22908
}

\begin{abstract}
To determine whether the expression of the type 1 angiotensin II receptor $\left(\mathrm{AT}_{1}\right)$ gene is developmentally regulated and whether the regulation is tissue specific, $\mathbf{A T}_{1}$ mRNA levels were determined by Northern blot analysis in livers and kidneys from fetal, newborn, and adult rats, using a 1133-bp rat $A T_{1}$ cDNA. In the liver, $A_{1}$ mRNA levels increased fivefold from $15 \mathrm{~d}$ gestation to $5 \mathrm{~d}$ of age. Liver $A T_{1}$ mRNA levels at $5 \mathrm{~d}$ of age were similar to those of adult rats. In the kidney, $\mathbf{A T}_{1}$ mRNA levels were higher in immature than in adult animals. The intrarenal distribution of $\mathrm{AT}_{1}$ mRNA was assessed by in situ hybridization to a ${ }^{35} \mathrm{~S}$-labeled 24 residues oligonucleotide complementary to rat $\mathrm{AT}_{1}$ mRNA. In the adult, $\mathrm{AT}_{1}$ mRNA was present in glomeruli, arteries, and vasa recta, whereas in the newborn $\mathrm{AT}_{1}$ mRNA was observed also over the nephrogenic area of the cortex.

We conclude that: $(a)$ fetal kidney and liver express the $\mathrm{AT}_{1}$ gene; (b) the $\mathrm{AT}_{1}$ gene expression is developmentally regulated in a tissue-specific manner; $(c)$ during maturation, localization of $\mathrm{AT}_{1}$ mRNA in the kidney shifts from a widespread distribution in the nephrogenic cortex to specific sites in glomeruli, arteries, and vasa recta, suggesting a role for the angiotensin receptor in nephron growth and development. (J. Clin. Invest. 1993. 91:530-537.) Key words: mRNA • in situ hybridization $\bullet$ liver $\bullet$ kidney $\bullet$ development
\end{abstract}

\section{Introduction}

During development the activity of the renin-angiotensin system (RAS) ${ }^{1}$ is markedly enhanced $(1,2)$. Circulating renin and angiotensin II (AngII) are increased in newborn and young animals $(3,4)$. Angiotensinogen and renin gene expression have been documented in the liver, brain, adrenal, and kidney of developing animals (5-7), illustrating the activity of local RAS. Functional AngII receptors have been demonstrated during fetal and early postnatal life in several tissues (8-12). Moreover, physiologic studies underscore the importance of the RAS during fetal and early postnatal life (13).

Address correspondence to R. Ariel Gomez, M.D., Department of Pediatrics, University of Virginia, MR4/Room 2001, Charlottesville, VA 22908.

Received for publication 27 January 1992 and in revised form 14 September 1992.

1. Abbreviations used in this paper: AngII, angiotensin II; $\mathrm{AT}_{1}$, type 1 angiotensin II receptor; PCR, polymerase chain reaction; RAS, reninangiotensin system.

J. Clin. Invest.

(C) The American Society for Clinical Investigation, Inc.

0021-9738/93/02/0520/08 \$2.00

Volume 91, February 1993, 530-537
In addition to its well-known role in the regulation of arterial blood pressure, fluid and electrolyte balance, and renal hemodynamics, AngII stimulates cell growth and expression of growth factors and growth-related protooncogenes (14-18). AngII actions are mediated by specific membrane receptors $(19,20)$. Two AngII receptors have been identified and characterized pharmacologically by binding affinity studies (21-23). Their distribution among tissues and species differ $(10,24)$. Although both AngII receptors have been detected in the liver, angiotensin type 1 receptor $\left(\mathrm{AT}_{1}\right)$ predominates $(25,26)$. In the kidney, autoradiographic studies have documented AngII binding to glomeruli and renal mesangial and epithelial cells, and the receptor was identified as $\mathrm{AT}_{1}(12,27-32)$. Recently, the $\mathrm{AT}_{1}$ receptor has been cloned and it has been suggested that its expression is developmentally regulated $(26,33)$.

Because of the pivotal role of AngII in the renin-angiotensin system, the characterization of $\mathrm{AT}_{1}$ receptor gene expression during ontogeny is crucial. Therefore, to determine whether the $\mathrm{AT}_{1}$ gene expression is regulated during development in a tissue-specific manner, $\mathrm{AT}_{1}$ mRNA levels were detected by Northern blot analysis in fetal, newborn, and adult kidneys and livers. In addition, the distribution of $\mathrm{AT}_{1}$ mRNA within the kidney was assessed by in situ hybridization in newborn and adult rats.

\section{Methods}

Time-dated pregnant and adult Wistar-Kyoto rats were purchased from Charles River Breeding Laboratories (Boston, MA) and maintained on regular rat chow (Purina 5012; Ralston-Purina, St. Louis, MO) and tap water until studied. Fetal age was determined as previously described (34). Rats were anesthetized with sodium pentobarbital ( $3 \mathrm{mg} / 100 \mathrm{~g}$ body wt, intraperitoneally) and killed by decapitation at various gestational $(15,17,18,20 \mathrm{~d})$ and postnatal ages $(1 \mathrm{~h}$, and 1 , 2, 5, 10, 30, and $90 \mathrm{~d}$ ). Kidneys and livers from fetuses, newborn, and adult rats were harvested and processed for Northern and dot blot analysis or in situ hybridization as described below.

Northern and dot blot analysis. Kidneys and livers were removed from 130 fetuses ( $15[n=24], 17[n=56], 18[n=10], 20[n=40] \mathrm{d}$ gestation ), 42 newborns $(1 \mathrm{~h}[n=8]$ and $1[n=8], 2[n=9], 5[n$ $=7], 10[n=10] \mathrm{d}$ old $)$ and 11 adults $(30[n=5]$ and $90[n=6] \mathrm{d}$ old $)$ and several pools were made for each age period. Total RNA was extracted (35), dissolved in sterile water, and stored at $-80^{\circ} \mathrm{C}$ until use. RNA concentration was determined spectrometrically at $260 \mathrm{~nm}$. Electrophoresis, transfer, and hybridization of RNA were performed as previously described $(7,36)$. In addition, dot blots with two or more RNA samples from different animal pools for each age were performed to allow statistical comparison of mRNA levels at different ages.

Hybridization probe. Two oligonucleotides (5'-GAT TTC GAA TAG TGT CTG AGA CC-3' and 5'-TTG AAC CTG TCA CTC CAC CTC AA-3') were synthesized on a synthesizer (model 8600; BioSearch, Millipore Corp., Bedford, MA) and purified by HPLC. These oligonucleotides were used to amplify, by the polymerase chain reaction (PCR) a 1133-bp fragment (nucleotides -44-1089) of cDNA encoding the rat $\mathrm{AT}_{1}$ receptor (26). The conditions for the PCR were $94^{\circ} \mathrm{C}$ for $1 \mathrm{~min}, 55^{\circ} \mathrm{C}$ for $2 \mathrm{~min}$, and $72^{\circ} \mathrm{C}$ for $3 \mathrm{~min}$, repeated for 25 cycles. The DNA was amplified from $\sim 1 \mathrm{ng}$ of cDNA synthesized 
from rat liver poly $\mathrm{A}^{+} \mathrm{RNA}$ (cDNA synthesis kit; Amersham Corp., Arlington Heights, IL). The specific fragment was purified from an agarose gel by electrophoresis onto DEAE-cellulose (37) and either used as the hybridization probe directly or subcloned into the SmaI site of pGEM 7(z)f(+). From the resultant plasmid a HindIII/Xbal fragment was isolated and used also as an hybridization probe. DNA fragments were labeled with [ ${ }^{32} \mathrm{P}$ ]dCTP to specific activities of 3.8-4.2 $\times 10^{9} \mathrm{dpm} / \mu \mathrm{g}$ by random priming (37). Hybridization signals were detected by autoradiography and quantitated by scanning densitometry (2222-020 Ultrascan XL laser densitometer; LKB Instruments Inc., Bromma, Sweden). For statistical purposes, densitometric data from fetal $(n=6)$, newborn ( $n=8$ liver, $n=6$ kidney), and adult ( $n$ $=4$ liver, $n=6$ kidney) age periods were compared as groups by analysis of variance. Statistical significance was defined as $P<0.05$.

In situ hybridization histochemistry. Kidneys from four newborn ( $2 \mathrm{~d}$ old ) and four adult rats ( $90 \mathrm{~d}$ old ) were processed for in situ hybridization as previously described with few modifications $(38,39)$. Briefly, kidneys from adult animals were perfusion fixed with $150 \mathrm{ml}$ of a $4 \%$ paraformaldehyde solution in $0.12 \mathrm{M} \mathrm{NaHPO}_{4}$ and kidneys from newborns were immersed in the same fixative solution. Subsequently, all kidneys were postfixed for $1 \mathrm{~h}$ in the same fixative solution and stored overnight at $4^{\circ} \mathrm{C}$ in cryoprotection solution ( $30 \%$ sucrose in 0.12 $\left.\mathrm{M} \mathrm{NaHPO}_{4}\right)$. Frozen sagittal sections $(14 \mu \mathrm{m})$ were cut and mounted on positively charged slides. Sections were prehybridized for $1 \mathrm{~h}$ at $37^{\circ} \mathrm{C}$ and hybridized for $24 \mathrm{~h}$ at $37^{\circ} \mathrm{C}$ to a 24 residues oligonucleotide (5'CAG-AAA-GCC-GTA-GAA-CAG-AGG-GTT-3') complementary to nucleotides 892-915 of rat $\mathrm{AT}_{1}$ mRNA (26). The nucleotide was labeled at the $3^{\prime}$ end with $\alpha$-thio- ${ }^{35}$ S-dATP to a specific activity of $1.22 \times 10^{7} \mathrm{dpm} \cdot \mathrm{pmol}^{-1}$. After hybridization, the sections were washed with decreasing concentrations of SSPE $(1 \times$ SSPE is $150 \mathrm{mM}$ $\mathrm{NaCl}, 10 \mathrm{mM} \mathrm{NaHPO}, 1 \mathrm{mM}$ EDTA, pH 7.4), containing $14 \mathrm{mM}$ 2-mercaptoethanol and $1 \%$ sodium thiosulfate, followed by a high stringency wash at $45^{\circ} \mathrm{C}$ for $30 \mathrm{~min}$ in $0.1 \times \operatorname{SSPE}(39)$. Then, sections were dehydrated, submitted to emulsion autoradiography, and stained with hematoxylin.

To test the specificity of the hybridization signals, the thermal stability of the hybrids was determined. 30 sections from newborn kidney were hybridized to the labeled probe as described above, and randomly allocated to high stringency washes at six different temperatures ranging from 40 to $60^{\circ} \mathrm{C}$. The number of grains over glomeruli and tubules were counted in each section and plotted against the temperature of the wash (in situ melting curve, Fig. 1). The 24-mer probe was removed from the sections over a narrow temperature range of $45-50^{\circ} \mathrm{C}$, which

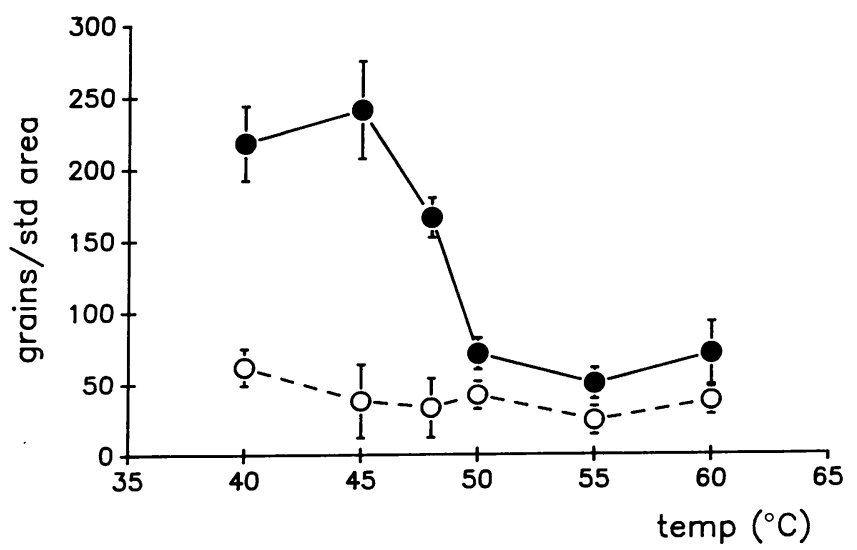

Figure 1. In situ thermal melting curve ( $\mathrm{Tm}$ ) for the 24 residues oligonucleotide complementary to nucleotides 895-912 of rat AT 1 receptor mRNA. The number of grains (mean \pm SEM) per standard area $\left(865 \mu \mathrm{m}^{2}\right)$ are plotted against the temperature of the high stringency wash. Hybrids are "melted" between 45 and $50^{\circ} \mathrm{C}$ in agreement with calculated Tm. •, Glomeruli; $\circ$, tubules. corresponded closely to the calculated melting temperature of $49.4^{\circ} \mathrm{C}$. Additional negative controls, as indicated by absence of hybridization signals, were hybridization with sense oligonucleotide labeled with ${ }^{35} \mathrm{~S}$ dATP as described above, 50-100-fold excess of cold oligonucleotide and omission of the probe.

To quantitate the changes in the intrarenal distribution of $\mathrm{AT}_{1}$ mRNA during development, in situ hybridization signals over each kidney structure were counted by computer digitization (IP 8500; Gould Electronics-Vicom Inc., Freemont, CA). The number of silver grains over glomeruli, vessels, and tubules was computed for each section and an average was obtained for newborn $(n=14)$ and adult $(n=$ 14 ) kidneys. Data are expressed as mean \pm SEM, after subtraction of background counts, unless otherwise indicated. Comparisons between grain counts were made by $t$ test for unpaired data. Statistical significance was defined as $P<0.05$.

\section{Results}

Kidney and liver total RNA from rats of different ages, resolved by Northern blot and hybridized with $\mathrm{AT}_{1} \mathrm{CDNA}$, show two transcripts ( $2.4 \mathrm{~kb}$ and $3.3 \mathrm{~kb}$ ) corresponding to the cloned $\mathrm{AT}_{1}$ cDNA (26). The smaller transcript is the more abundant (Figs. $2 A$ and $3 A$ ). The 3.3-kb transcript is very faint in the autoradiograms and is not visualized in the reproductions.

$\mathrm{AT}_{1}$ gene expression undergoes marked alterations during early development. In the liver, $\mathrm{AT}_{1} \mathrm{mRNA}$ was detectable at $15 \mathrm{~d}$ gestation and increased fivefold thereafter during fetal and early postnatal life (Fig. 2). Liver AT ${ }_{1}$ mRNA levels at $5 \mathrm{~d}$ of age were similar to the adult animal. In the kidney, $\mathrm{AT}_{1}$ mRNA levels were higher in inmature than in adult animals (Fig. 3). Kidney $\mathrm{AT}_{1}$ mRNA levels increased twofold between $17 \mathrm{~d}$ gestation and $5 \mathrm{~d}$ of age. $\mathrm{AT}_{1} \mathrm{mRNA}$ levels in adult animals were two- to threefold lower than at $5 \mathrm{~d}$ of age. Interestingly, the expression of $\mathrm{AT}_{1}$ mRNA decreased transiently in the first day of life, and returned to the level at birth within the following $4 \mathrm{~d}$ in both organs (Figs. 2 and 3 ).

Fig. 4 illustrates the intrarenal distribution of $\mathrm{AT}_{1} \mathrm{mRNA}$ in the adult kidney. Specific hybridization signals were observed in the glomeruli, arteries of all sizes, and vasa recta. The abundance of hybridization signals was similar in glomeruli from the inner and outer cortex. The distribution of grains within glomeruli was homogeneous (Fig. $4 A$ ). Occasionally, grains were clustered towards the vascular pole. In the vessels, grains were observed over the media (Fig. $4 B$ ). A very low number of grains was detected over the tubules, indistinguishable from background. Figs. 5 and 6 show the intrarenal distribution of $\mathrm{AT}_{1}$ mRNA in the newborn kidney. In the renal cortex of the newborn rat, nephrons at different stages of maturation were observed, ranging from S-shaped corpuscles in the subcapsular region to functional nephrons with glomeruli and eosinophilic proximal convoluted tubules in the juxtamedullary zone. Specific hybridization signals were observed in the glomeruli and arteries of the inner cortex (Fig. 5), similar to those described in the adult kidney. In addition, abundant hybridization signals were distributed over the nephrogenic area of the outer cortex (Fig. 6). Again, very low numbers of grains were observed over the mature tubuli of the inner cortex. In the medulla, hybridization signals were limited to the radiating bundles corresponding to the vasa recta.

Table I summarizes the quantitation of hybridization signals in newborn and adult kidneys. The number of hybridization signals in glomeruli was higher in the newborn than in the adult kidney (Table I, $P<0.05$ ). No differences were detected 


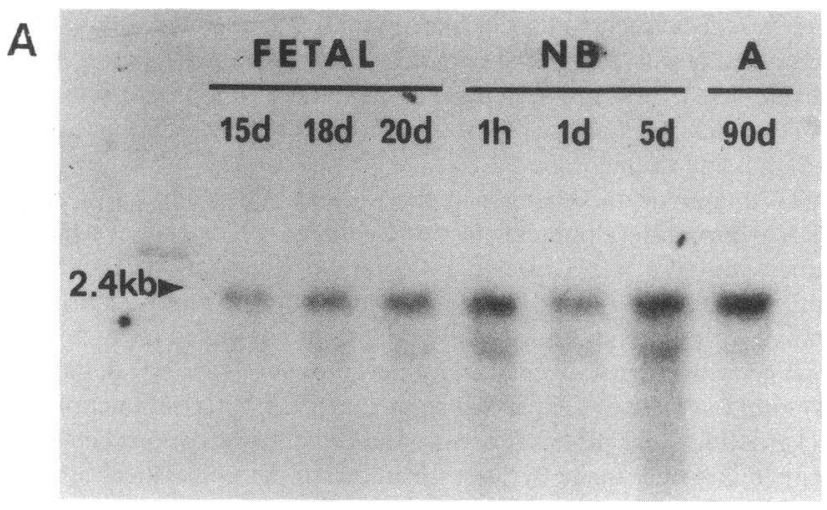

B
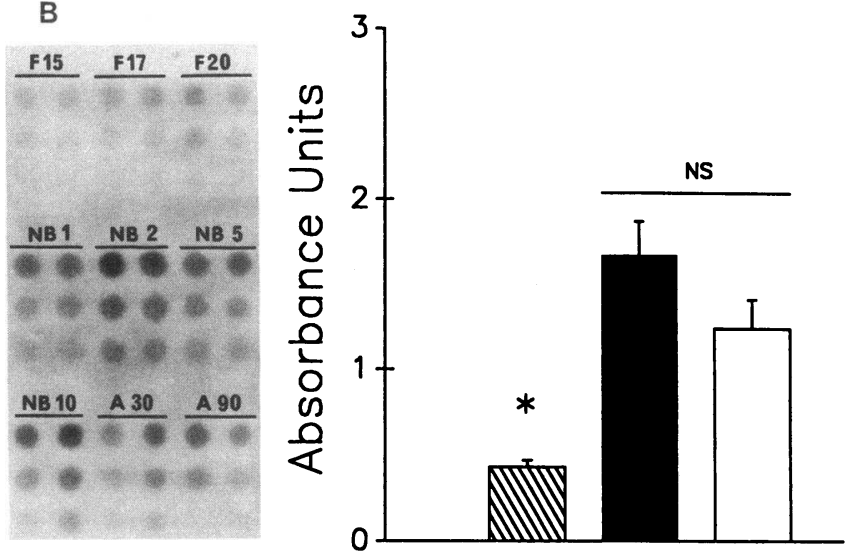

Figure 2. Liver $\mathrm{AT}_{1}$ mRNA accumulation in fetal, newborn $(N B)$, and adult $(A)$ rats. $(A)$ Northern blot. $15 \mathrm{~d}, 18 \mathrm{~d}$, and $20 \mathrm{~d}$ represent days of gestation; $1 \mathrm{~h}, 1 \mathrm{~d}, 5 \mathrm{~d}$, and $90 \mathrm{~d}$ represent hours/days of postnatal life. Liver total RNA pooled from 4-10 animals $(5 \mu \mathrm{g})$ was loaded into each lane. Hybridization to ${ }^{32} \mathrm{P}-\mathrm{AT}_{1}$ cDNA (sp act 4.2 $\times 10^{9} \mathrm{cpm} / \mu \mathrm{g}$ ). Exposure time $2 \mathrm{~d}$ on Kodak XAR film with intensifying screen. $(B)$ Dot blot with corresponding densitometric analysis. Two RNA samples from different animal pools for each age were blotted. F15, F17, F20 represent days of gestation; NB1, NB2, NB5, NB10, A30, and A90 represent days of postnatal life. $4 \mu \mathrm{g}$ total RNA were loaded in the first row, serial 1:2 dilutions were loaded subsequently. Hybridization to ${ }^{32} \mathrm{P}-\mathrm{AT}_{1} \mathrm{cDNA}$ ( $\mathrm{sp}$ act $4 \times 10^{9} \mathrm{cpm} / \mu \mathrm{g}$ ). Exposure time $3 \mathrm{~d}$. The bar graph summarizes densitometric data, expressed as mean \pm SEM. For statistical purposes, fetal $(n=6)$, newborn $(n=8)$, and adult $(n=4)$ age periods were compared as groups. ${ }^{*} P<0.05$. $ه$, Fetal; $₫$, newborn; $\square$, adult.

in the concentration of hybridization signals in vessels from newborn and adults. In newborn kidneys, the nephrogenic area had lower concentrations of $\mathrm{AT}_{1}$ mRNA than the glomeruli (Table I, $P<0.05$ ). In newborn and adult kidneys, grain counts per tubular sections were lower than in any other renal structure ( Table I). Grain counts in the tubules were not different from background counts, did not change throughout the melting temperature experiment, (Fig. 1), and therefore represent background.

\section{Discussion}

The present study demonstrates that: $(a)$ the fetal kidney and liver express the $\mathrm{AT}_{1}$ receptor gene; $(b)$ the expression of the $\mathrm{AT}_{1}$ receptor gene is developmentally regulated; $(c)$ the changes in the abundance of $\mathrm{AT}_{1}$ receptor mRNA during maturation are organ specific. Thus, in the liver $\mathrm{AT}_{1} \mathrm{mRNA}$ increases with maturation whereas in the kidney it decreases. Finally, the intrarenal distribution of $\mathrm{AT}_{1} \mathrm{mRNA}$ changes with maturation: from a widespread distribution over the nephrogenic cortex in the newborn to a more discrete location in glomeruli, arteries, and vasa recta in the adult animal. Our findings confirm and extend to earlier ages previous studies reporting developmental changes in liver and kidney $\mathrm{AT}_{1}$ receptor mRNA levels using PCR $(26,33)$.

In the present study, we detected for the first time $\mathrm{AT}_{1}$ mRNA in the fetal liver at $15 \mathrm{~d}$ of gestation. These findings are in agreement with previous AngII binding and autoradiographic studies $(10,24)$. Although the function of the RAS in the liver during fetal life remains unclear it may play a role in the accelerated growth occurring at this stage of development.
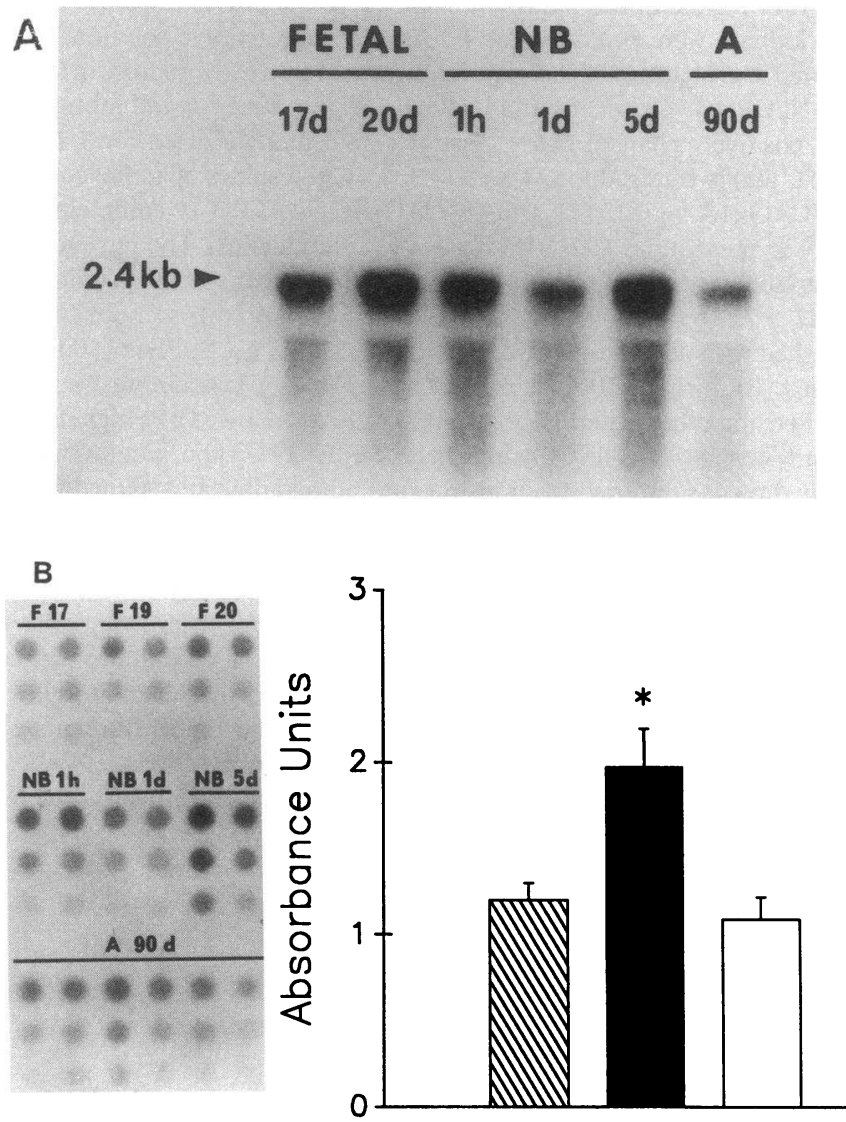

Figure 3. Kidney AT, mRNA accumulation in fetal, newborn, and adult rats. $(A)$ Northern blot. Abbreviations are as described for Fig. 2. Kidney total RNA pooled from 4-10 animals $(20 \mu \mathrm{g})$ was loaded into each lane. Hybridization to ${ }^{32} \mathrm{P}-\mathrm{AT}_{1}$ cDNA (sp act $4.2 \times 10^{9}$ $\mathrm{cpm} / \mu \mathrm{g}$ ). Exposure time $7 \mathrm{~d}$ on Kodak XAR film with intensifying screen. $(B)$ Dot blot with corresponding densitometric analysis. Two RNA samples from different pools for each gestational (F17, F19, F20) and neonatal age (NB1h, NB1d, NB5d) and six RNA samples from individual adult rats were blotted. $4 \mu \mathrm{g}$ total RNA was loaded in the first row, serial 1:2 dilutions were loaded subsequently. Hybridization to ${ }^{32} \mathrm{P}-\mathrm{AT}_{1} \mathrm{cDNA}$ ( $\mathrm{sp}$ act $4 \times 10^{9} \mathrm{cpm} / \mu \mathrm{g}$ ). Exposure 4 d. Bar graph summarizes densitometric data expressed as mean \pm SEM. For statistical purposes fetal $(n=6)$, newborn $(n=6)$, and adult $(n=6)$ age periods were compared as groups. ${ }^{*} P<0.05$.

$\square$, Fetal; $\bullet$, newborn; $\square$, adult. 

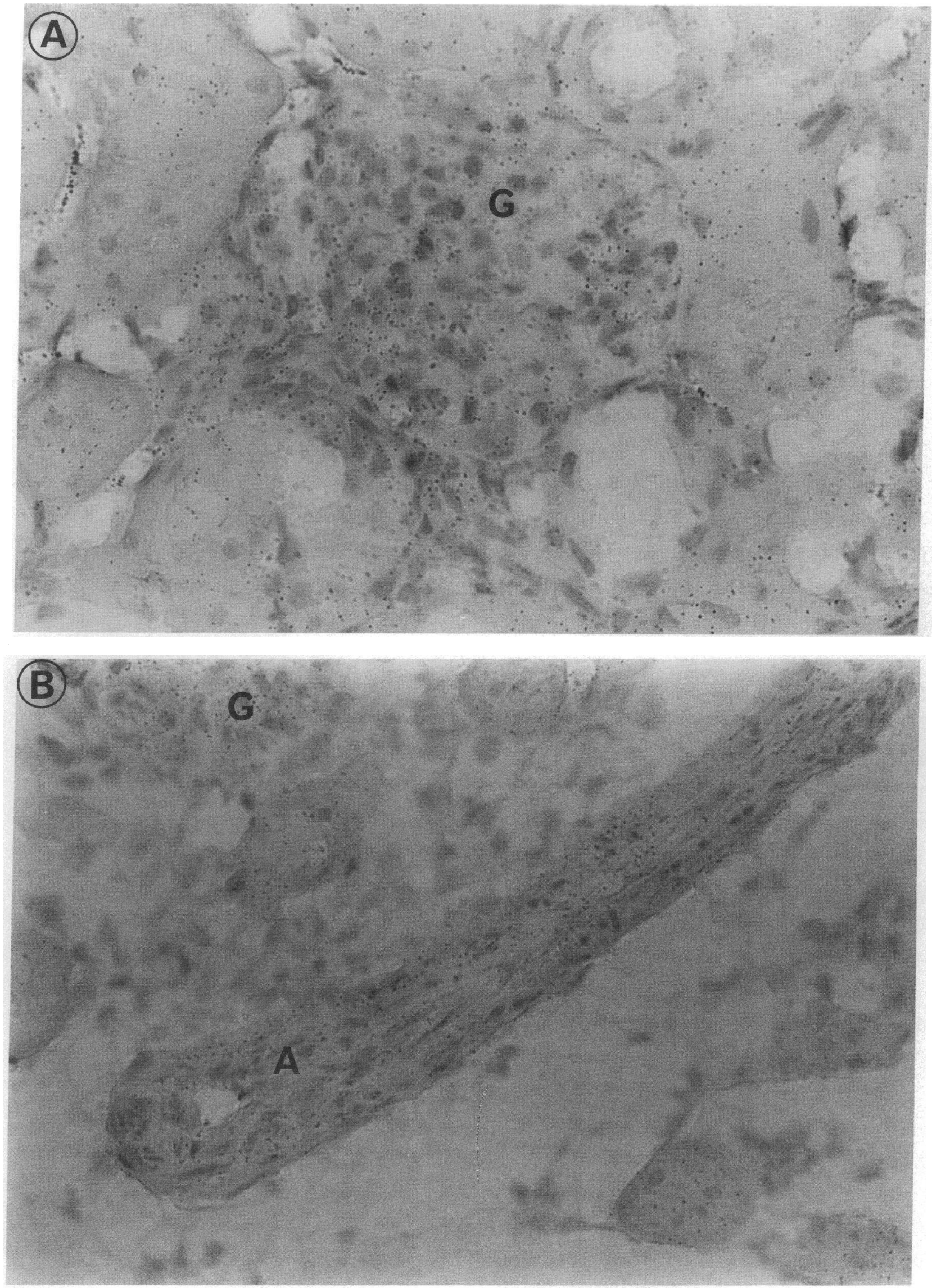

Figure 4. In situ hybridization for $\mathrm{AT}_{1}$ receptor mRNA. Representative kidney tissue section from an adult rat. $(A)$ Hybridization signals (silver grains) are localized to the glomerulus $(G)$. Magnification, 500. (B) Hybridization signals are localized to the media of the artery $(A)$. Magnification, 500. Emulsion autoradiography using NTB2. Exposure time $28 \mathrm{~d}$. 

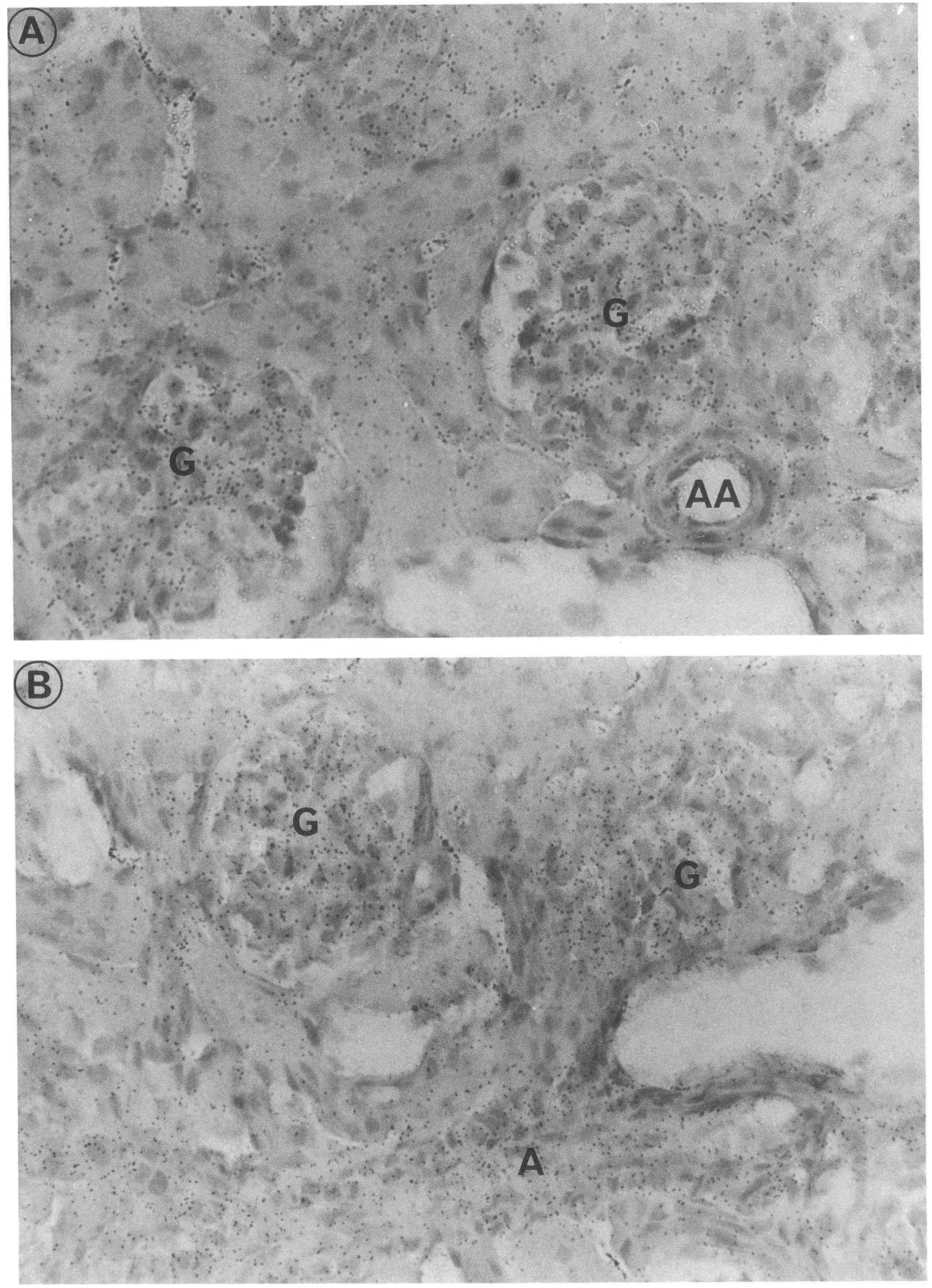

Figure 5. In situ hybridization for $\mathrm{AT}_{1}$ receptor mRNA. Representative kidney tissue section from a newborn rat. $(A)$ Hybridization signals are located in the glomeruli $(G)$ and afferent arteriole $(A A)$. $(B)$ Hybridization signals are located in glomeruli $(G)$ and along the adjacent artery (A). Magnification, 500. Exposure time $28 \mathrm{~d}$. 


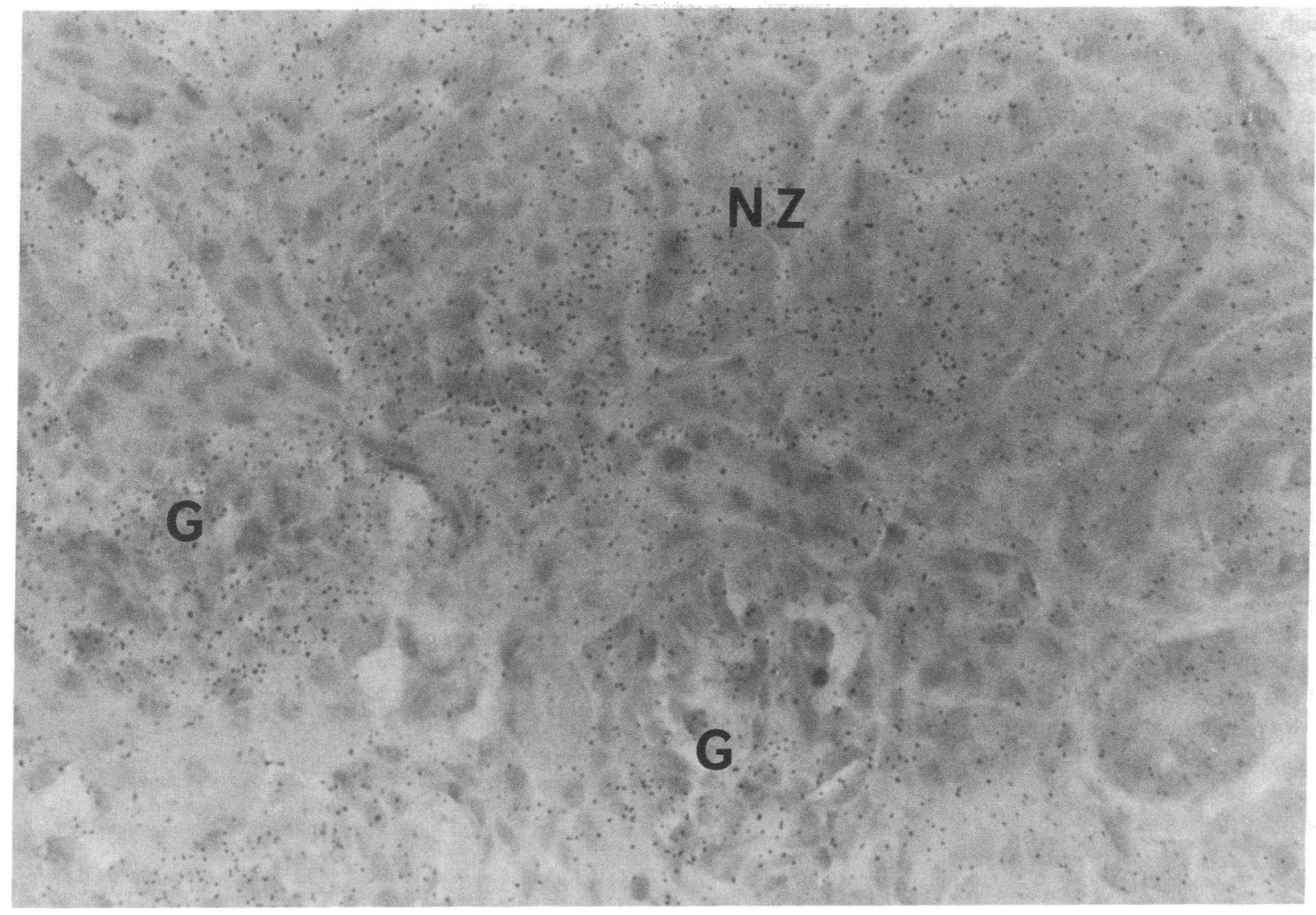

Figure 6. In situ hybridization for $\mathrm{AT}_{1}$ receptor mRNA. Representative kidney tissue section from a newborn rat. Hybridization signals are scattered throughout the nephrogenic zone $(N Z)$ of the renal cortex. Magnification, 500. Exposure time $28 \mathrm{~d}$.

A positive feedback has been described in adult rat liver whereby high levels of AngII increase angiotensinogen gene expression $(40,41)$. In the fetal liver angiotensinogen mRNA levels are very low before $20 \mathrm{~d}$ gestation, increasing immediately after birth to adult levels $(5,42)$. In contrast, increasing levels of $\mathrm{AT}_{1}$ mRNA are detected in the fetal liver during the third week of gestation. Thus, expression of $\mathrm{AT}_{1}$ receptor gene precedes angiotensinogen gene expression in the fetal liver. The time course of expression of the $\mathrm{AT}_{1}$ and angiotensinogen genes may be compatible with a role for AngII in the induction

Table I. Quantitation of Hybridization Signals in Newborn and Adult Kidneys

\begin{tabular}{lcccc}
\hline & Glomeruli & $\begin{array}{c}\text { Nephrogenic } \\
\text { cortex }\end{array}$ & Vessels & Tubules \\
\hline & grains/A & grains $/ A$ & grains/A & grains $/ A$ \\
$\begin{array}{l}\text { Newborn } \\
(n=14)\end{array}$ & $543 \pm 68^{*}$ & $234 \pm 50^{\ddagger}$ & $366 \pm 47^{\S}$ & $36 \pm 8^{\prime \prime}$ \\
$\begin{array}{l}\text { Adult } \\
(n=14)\end{array}$ & $296 \pm 42$ & - & $422 \pm 68$ & $52 \pm 15^{\prime \prime}$ \\
\hline
\end{tabular}

A, standardized area $\left(865 \mu \mathrm{m}^{2}\right)$; data are expressed as mean $\pm \mathrm{SEM}$; ${ }^{*} P<0.05$ newborn vs adult; ${ }^{\ddagger} P<0.05$ nephrogenic area vs glomeruli; $\$ P<0.05$ vessels vs glomeruli; " background counts were not subtracted. of angiotensinogen expression in the fetal liver, thus initiating the positive feedback loop described for the adult animal.

In the kidney, $\mathrm{AT}_{1}$ mRNA increases during late gestation and the first week of life. Overall, developing kidneys express higher levels of $\mathrm{AT}_{1}$ mRNA than adult ones. The intrarenal distribution of the $\mathrm{AT}_{1}$ receptor mRNA in the adult kidney described in the present study is in agreement with the localization of AngII binding sites and physiologic effects (30, 32, 43, $44)$. In the newborn rat, we observed a broad distribution of hybridization signals in the nephrogenic area of the cortex and increased $\mathrm{AT}_{1}$ mRNA accumulation in the glomeruli, supporting the possible role of AngII in accelerated nephron growth and/or maturation $(14,44)$.

The pattern of $\mathrm{AT}_{1}$ mRNA expression during maturation reproduces the changes in circulating renin, AngII, and AngIIbinding sites reported in developing animals $(3,10,43)$. Furthermore, the changes in renal AT 1 mRNA reported in the present study resemble the pattern of maturation of intrarenal renin mRNA $(7,34,39)$. The basis for this timing of coexpression of renin and $\mathrm{AT}_{1}$ genes in the developing kidney is presently unknown. Immaturity of the intracellular signal that mediates AngII negative feedback on renin gene expression in the adult rat could result in upregulation of renin during early development (45). Alternatively, AngII feedback could be reset at a higher level. However, these hypotheses remain to be tested.

$\mathrm{AT}_{1}$ gene expression in renal tubules, if any, is extremely low both in the newborn and in the adult kidney. As demonstrated in Fig. 1 the grain counts over the tubules were similar 
at every high stringency wash temperature tested, indicating nonspecific binding. These findings suggest either that the receptors detected by AngII binding are from a different subtype (46) or that the level of expression of the $\mathrm{AT}_{1}$ receptor is below the sensitivity of in situ hybridization. AngII binding sites reported in renal tubular cells, were characterized as low affinity $A T_{1}$ receptors (31). However, it was recently shown that AngII binding was partially abolished by specific $\mathrm{AT}_{1}$ and $\mathrm{AT}_{2}$ antagonists (Dup 753 and PD123177), suggesting that two receptor subtypes were present (46-48). Receptor heterogeneity in proximal tubule cells is further supported by different signal transduction pathways $(20,24)$ and opposite effect of various AngII concentrations (49).

The localization of $\mathrm{AT}_{1}$ mRNA over glomeruli and the media of arteries suggests that the receptor is expressed in smooth muscle-like cells $(16,50)$, although we can not rule out its presence in other cell types.

In summary, $\mathrm{AT}_{1}$ gene expression is detected in fetal rat liver and increases with maturation. $\mathrm{AT}_{1}$ gene is expressed at high levels in fetal rat kidney and decreases during development. As maturation progresses, the intrarenal distribution of $\mathrm{AT}_{1}$ mRNA shifts toward predominant vascular and glomerular sites. We speculate that these changes in $\mathrm{AT}_{1}$ gene expression are involved in the regulation of renin gene expression and nephron growth and maturation.

\section{Acknowledgments}

The technical assistance of John P. Elwood and Neysa Wilfong is greatly appreciated.

Dr. Tufro-McReddie is the recipient of an American Heart Fellowship Award VA-91-62. Dr. Gomez is supported by the National Heart, Lung, and Blood Institute (HL-41899), a research Career Development Award (HL-02307), and the Center of Excellence in Pediatric Nephrology and Urology (DK-44756).

\section{References}

1. Gomez, R. A., R. L. Chevalier, R. M. Carey, and M. J. Peach. 1990. Molecular biology of the renin-angiotensin system. Kidney Int. 38(Suppl. 30):S18-S23.

2. Krieger, J. E., and V. J. Dzau. 1991. Molecular biology of hypertension. Hypertension (Dallas). 18(Suppl. I):I3-I17.

3. Wallace, K. B., J. B. Hook, and M. D. Bailie. 1980. Postnatal development of the renin-angiotensin system in rats. Am. J. Physiol. 238:R432-R437.

4. Wallace, K. B., S. Oparil, and M. D. Bailie. 1981. Angiotensin II metabolism by tissues from developing rats. Pediatr. Res. 15:1088-1092.

5. Gomez, R. A., L. Cassis, K. R. Lynch, R. L. Chevalier, N. Wilfong, R. M. Carey, and M. J. Peach. 1988. Fetal expression of the angiotensinogen gene Endocrinology. 123:2298-2302.

6. Jones, C. A., C. D. Sigmund, R. A. McGowan, C. M. Kaqne-Haas, and K. W. Gross. 1990. Expression of murine renin genes during fetal development. Mol. Endocrinol. 4:375-383.

7. Gomez, R. A., K. R. Lynch, R. L. Chevalier, N. Wilfong, A. D. Everett, R. M. Carey, and M. J. Peach. 1988. Renin and angiotensinogen gene expression in maturing rat kidney. Am. J. Physiol. 254:F582-587.

8. Uva, B., M. Vallarino, and P. Ghiani. 1985. Heterogeneity of angiotensin I receptors in membranes of developing rat metanephros. Cell Biochem. Funct. 3:273-276

9. Jones, C., M. A. Millan, F. Naftolin, and G. Aguilera. 1989. Characterization of angiotensin II receptors in the rat fetus. Peptides (Elmsford). 10:459-463.

10. Millan, M. A., P. Carvallo, S. I. Izumi, S. Zemel, K. J. Catt, and G. Aguilera. 1989. Novel sites of expression of functional angiotensin II receptors in the late gestation fetus. Science (Wash. DC). 244:1340-1342.

11. Tsutsumi, K., C. Stromberg, M. Viswanathan, and J. M. Saavedra. 1991. Angiotensin-II receptor subtypes in fetal tissues of the rat: autoradiography, guanine nucleotide sensitivity, and association with phosphoinositides hydrolysis Endocrinology. 129:1075-1082.

12. Grady, E. F., L. A. Sechi, C. A. Griffin, M. Schamberlan, and J. E. Kalin- yak. 1991. Expression of AT2 receptors in the developing rat fetus. J. Clin. Invest. 88:921-933.

13. Robillard, J. E., and K. T. Nakamura. 1988. Neurohumoral regulation of renal function during development. Am. J. Physiol. 254:F771-F779.

14. Norman, J. T. 1991. The role of angiotensin II in renal growth. Renal Physiol. Biochem. 14:175-185.

15. Wolf, G., and E. G. Neilson. 1990. Angiotensin II induces cellular hypertrophy in cultured murine proximal tubular cells. Am. J. Physiol. 259:F768F777.

16. Owens, G. K. 1989. Control of hypertrophic versus hyperplastic growth of vascular smooth muscle cells. Am. J. Physiol. 257:H1755-1765.

17. Araki, S., Y. Kawahara, K. Kariya, M. Sunako, T. Tsuda, H. Fukuzaki, and T. Yoshimi. 1990. Stimulation of platelet-derived growth factor-induced DNA synthesis by angiotensin II in rabbit vascular smooth muscle cells. Biochem. Biophys. Res. Commun. 168:350-357.

18. Naftilan, A. J., G. K. Gilliland, C. S. Eldridge, and A. S. Kraft. 1990 Induction of the proto-oncogene c-jun by angiotensin II. Mol. Cell. Biol. $10: 5536-5540$

19. Griendling, K. K., T. Tsuda, B. C. Berk, and R. W. Alexander. 1989 Angiotensin II stimulation of vascular smooth muscle. J. Cardiovasc. Pharmacol. 14(Suppl. 6):S27-S33.

20. Douglas, J. C., M. Romero, and U. Hopfer. 1990. Signaling mechanisms coupled to the angiotensin receptor of proximal tubular epithelium. Kidney Int. 38:S43-S47.

21. Chiu, A. T., D. E. McCall, P. E. Aldrich, and P. B. M. W. M. Timmermans. 1990. [3H]DuP 753, a highly potent and specific radioligand for the angiotensin II-1 receptor subtype. Biochem. Biophys. Res. Commun. 172:1195-1202.

22. Chiu, A. T., W. F. Herblin, D. E. McCall, R. J. Ardecky, D. J. Carini, J. V. Duncia, L. J. Pease, P. C. Wong, R. R. Wexler, A. L. Johnson, and P. B. M. W. M. Timmermans. 1989. Identification of angiotensin II receptor subtypes. Biochem. Biophys. Res. Commun. 165:196-203.

23. Bumpus, F. M., K. J. Catt, A. T. Chiu, M. DeGasparo, T. Goodfriend, A Husain, M. J. Peach, D. G. Taylor, and P. B. M. W. M. Timmermans. 1991 Nomenclature for angiotensin receptors. A report of the Nomenclature Committee of the Council for High Blood Pressure Research. Hypertension (Dallas). 17:720-721.

24. Catt, K., and A. Abbott. 1991. Molecular cloning of angiotensin II receptors may presage further receptor subtypes. Trends Pharmacol. Sci. 121:279-281.

25. Bauer, P. H., A. T. Chiu, and J. C. Garrison. 1991. DuP753 can antagonize the effects of angiotensin II in rat liver. Mol. Pharmacol. 39:579-585.

26. Murphy, T. J., R. W. Alexander, K. K. Griendling, M. S. Runge, and K. E. Bernstein. 1991. Isolation of a cDNA encoding the vascular type-1 angiotensin II receptor. Nature (Lond.). 351:233-236.

27. Osborne, M. J., B. Droz, P. Meyer, and F. Morel. 1975. Angiotensin II: renal localization in glomerular mesangial cells by autoradiography. Kidney Int $8: 245-254$

28. Skorecki, K. L., B. J. Ballermann, H. G. Rennke, and B. M. Brenner. 1983. Angiotensin II receptor regulation in isolated renal glomeruli. Fed. Proc 42:3064-3070.

29. Gehlert, D. R., R. C. Speth, and J. K. Wamsley. 1984. In vitro autoradiographic localization of $\left({ }^{125} \mathrm{I}\right)$-angiotensin $\mathrm{II}$ binding sites in the rat and dog kidney. Peptides (Elmsford). 5:1043-1048

30. Mendelsohn, F. A. O., M. Dunbar, A. Allen, S. T. Chou, M. A. Millan, and G. Aguilera. 1986. Angiotensin II receptors in the kidney. Fed. Proc 45:1420-1425.

31. Douglas, J. G. 1987. Angiotensin receptor subtypes of the kidney cortex Am. J. Physiol. 253:F1-F7.

32. Sechi, L. A., E. F. Grady, C. A. Griffin, J. E. Kalinyak, and M. Schamberlan. 1992. Distribution of angiotensin receptor subtypes in rat and human kidney. Am. J. Physiol. 262:F236-240.

33. Iwai, N., Y. Yamano, S. Chaki, F. Konishi, S. Bardhan, C. Tibbets, K. Sasaki, M. Hasegawa, Y. Matsuda, and T. Inagami. 1991. Rat angiotensin I receptor: cDNA sequence and regulation of the gene expression. Biochem. Biophys. Res. Commun. 177:299-304.

34. Gomez, R. A., R. L. Chevalier, B. C. Sturgill, D. W. Johns, M. J. Peach, and R. M. Carey. 1986. Maturation of the intrarenal renin distribution in WistarKyoto rats. J. Hypertens. 4(Suppl. 5):S31-S33.

35. Chirgwin, J. M., A. E. Przybla, R. J. MacDonald, and W. J. Rutter. 1979. Isolation of biologically active ribonucleic acid from sources enriched for ribonucleases. Biochemistry. 18:5294-5299.

36. Church, G. M., and W. Gilbert. 1984. Genomic sequencing. Proc. Natl. Acad. Sci. USA. 81:1991-1995.

37. Sambrook, J., E. F. Fritsch, and T. Maniatis. 1989. Molecular Cloning: A Laboratory Manual. Cold Spring Harbor Laboratory, Cold Spring Harbor, NY. pp. 6.24 and 10.14

38. Lynch, K. R., C. L. Hawelu-Johnson, and P. Guyenet. 1987. Localization of brain angiotensinogen mRNA by hybridization histochemistry. Mol. Brain Res. 2:149-158.

39. Gomez, R. A., K. R. Lynch, B. C. Sturgill, J. P. Elwood, R. L. Chevalier, 
R. M. Carey, and M. J. Peach. 1989. Distribution of renin mRNA and its protein in the developing rat kidney. Am. J. Physiol. 257:F850-F858.

40. Klett, C., and E. Hackenthal. 1987. Induction of angiotensinogen synthesis and secretion by angiotensin II. Clin. Exp. Hypertens. Part A Theory Pract. 9:2027-2047.

41. Nakamura, A., H. Iwao, K. Fukui, S. Kimura, T. Tamaki, S. Nakanishi, and Y. Abe. 1990. Regulation of liver angiotensinogen and kidney renin mRNA levels by angiotensin II. Am. J. Physiol. 258:E1-E6.

42. Everett, A. D., R. L. Chevalier, and R. A. Gomez. 1991. Hepatic angiotensinogen gene regulation in the fetal and pregnant rat. Pediatr. Res. 30:252-255.

43. Zemel, S., M. A. Millan, P. Feuillan, and G. Aguilera. 1990. Characterization and distribution of angiotensin-II receptors in the primate fetus. J. Clin. Endocrinol. \& Metab. 71:1003-1007.

44. Ichikawa, I., and R. C. Harris. 1991. Angiotensin actions in the kidney: renewed insight into the old hormone. Kidney Int. 40:583-596.

45. Johns, D. W., M. J. Peach, R. A. Gomez, T. Inagami, and R. M. Carey.
1990. Angiotensin II regulates renin gene expression. Am. J. Physiol. 259:F882F887.

46. Ernsberger, P., J. Zhou, and J. G. Douglas. 1991. Renal angiotensin receptor subtypes. Council on the Kidney in Cardiovascular Disease. Newsletter. Fall: $1-4$.

47. Burns, K. D., Y. Yamano, T. Inagami, and R. C. Harris. 1991. Angiotensin II receptor subtypes in mammalian proximal tubule. J. Am. Soc. Nephrol. 2:395. (Abstr.)

48. Xie, M. H., F. J. Liu, P. C. Wong, P. B. M. W. M. Timmermans, and M. G. Cogan. 1990. Proximal nephron and renal effects of Dup753, a nonpeptide angiotensin II receptor antagonist. Kidney Int. 38:473-479.

49. Schuster, V. L. 1986. Effects of angiotensin on proximal tubular reabsorption. Fed. Proc. 45:1444-1447.

50. Ray, P. E., G. Aguilera, J. B. Kopp, S. Horikoshi, and P. E. Klotman. 1991. Angiotensin II receptor-mediated proliferation of cultured human fetal mesangial cells. Kidney Int. 40:764-771. 